\title{
SAFETY AND HEALTH RISK ASSESSMENT AT OMAN BUILDING CONSTRUCTION PROJECTS
}

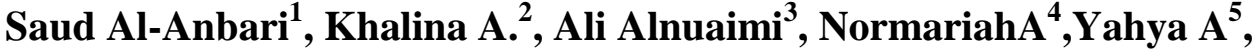 \\ ${ }^{.1}$ Ph.D. candidate, Faculty of Engineering, Universiti Putra Malaysia, Serdang, Malaysia \\ ${ }^{2}$ Aerospace Manufacturing Research Centre, Faculty of Engineering, Universiti Putra Malaysia,Serdang, Malaysia \\ ${ }^{3}$ Associate Professor, Department of Civil and Architectural Engineering, College of Engineering, \\ Sultan Qaboos University, Oman \\ ${ }^{4}$ Department of Mechanical and Manufacturing Engineering, Faculty of Engineering Universiti Putra Malaysia, \\ Serdang, Malaysia \\ ${ }^{5}$ Associate Professor, Department of Biological and Agricultural Engineering, Faculty of Engineering, \\ Universiti Putra Malaysia, Serdang, Malaysi,
}

\begin{abstract}
In this research a field survey was conducted via 30 interviews with safety and health experts and risk management staff in the field of construction industry in Oman followed by a questionnaire divided into six categories. 151 responses were analysed. The aim was to explore the availability, awareness, type and implementation of ORA. Six key risks were identified; namely: working at heights; working on fragile roofs; using electrical equipment; working under high voltage overhead power lines; working in confined spaces; working without knowing how to use the provided emergency equipment. All respondents were male gender and 61 per cent of them were below the age of 40.59 per cent of respondents have education equal to or below the national diploma ( $\leq 12$ level). 75.5 per cent of the respondents work in construction industry followed by the consultants (19\%). 53 per cent of respondents were labourers and technicians. 96 per cent of projects were residential, commercial or a combination of residential and commercials buildings. 81.3 per cent of workers were having equal or less than 10 years of experience in the construction projects. 53 per cent of respondents never experienced fatality during their work. 53.6 per cent of respondents indicated that they do not have Risk Assessment Matrix for Occupational Safety and Health. All respondents agreed that it is important or very important to apply Occupational Risk Assessment Matrix in accordance with the local regulations. Only 42.4 per cent strongly agree that HSE personal should carry out risk assessment before any activity. Most respondents showed willingness of applying risk management by workers.
\end{abstract}

Index Terms: Safety, Health, Risk, Assessment, occupational health, Oman

\section{INTRODUCTION}

Building Construction is extremely hazardous workplace where most frequently non-fatal and fatal vocational injuries occur due to its unique nature as stated by $\operatorname{Im}[1]$. Watfa [2]reported that 4 per cent of the world's Gross Domestic Product GDP is lost as the cost of occupational injuries and diseases. Hinze et al[3] examined 136,000 profiles of construction work injuries and found that the percentage of injuries that involved lacerations was considerably higher for construction than for all other industries. Baradan and Usmen[4] studied occupational injury and fatality risk analysis in 16 building trades. It was observed that ironworkers and roofers were the highest risk trades. To evaluate the risks, risk assessment matrices are widely used. Most current risk matrices are designed based on brain storming sessions which make them risky to use since they are based on experiences and knowledge on taken the decision. Cox [5] described the existing risk matrices as experiencing several problematic mathematical features making them harder to assess risks, including poor resolutions, errors, suboptimal resources allocation, and ambiguous inputs and outputs. He suggested that risk matrices should be used with caution, and only with careful explanations of embedded judgments. Ho[6] stated that the most popular risk assessment methods are/may be the least effective. There is a strong "placebo effect" in analysis even a completely ineffective method would feel like it worked, particular when it is easy to master. Even in organizations with extensive performance metrics, one of the most important measures is almost always ignored - the effectiveness of its risk management process. He suggested that users of risk matrix to be careful due to many limitations. Pinto et al[7] criticized the exiting occupational risk assessment (ORA) in construction industry as rampant with inadequate data and/or imprecise and incomplete information, particularly in the design stage, for which traditional quantitative approaches do not give adequate answers. They found that fuzzy approach is the best among all methods used in assessing risks in the construction 
industry. They claimed that fuzzy approach is quite flexible and yields a more realistic representation and solution for evaluation of risks in the construction industry. Nasirzadehet al[8] proposed a system dynamics SD approach to construction project risk management including risk analysis and response process. They used fuzzy logic integrated into system dynamics modelling structure to overcome problems of imprecise and uncertain nature of risks. Xiue-e and Zhen [9] proposed a fuzzy optimization model to evaluate the value of risk in construction industry and they found it gives better solution than the traditional fuzzy methods. Imriyas[10] proposed a fuzzy expert system that performs accident control at construction sites via Workers Compensation Insurance WCI premium for contractors.

It is clear from the above literature, and other, that the construction industry suffers serious fatal and non-fatal vocational incidents due to the extensive use of people in works that are dangerous. The impact of occupational illnesses and injuries are not only affecting safety and health, but also affecting economics and environmental aspects. That is because of the high costs associated with work injuries and effects on sustainable development. The existing methods of identifying and assessing risks in construction industry lack statistical analysis and valuation. Therefore, there is a considerable need to have an effective safety and health risk assessment procedure to improve the construction project performance. The risk assessment is used in assessing the risk, its impact, and provides protective measures for making decision. Identifying the risk is the first step of Risk Assessment of Safety and Health (RASH) method, where potential risks associated with projects in construction are identified. Although, up to date there is no research work was found in the literature about occupational safety and health risk assessment in building construction in Oman, some statistics of accidents (Watfa[2])show important such procedure is.

In this research, occupational safety and health key risks in building construction in Oman were identified; the awareness and assessment level and procedure are studied.

\section{METHODOLOGY}

To identify and assess the risks in the construction industry in Oman, a field survey was conducted via a questionnaire which was developed by the authors. The questionnaire was developed after30 interviews with Safety and Health Experts and risk management staff in the field of construction industry, in order to explore their opinions on the types and definitions of risks. As a result of these interviews, sixteen work activities were listed to cause fatalities and accidents in construction industry in Oman. These listed activities were used as part of the survey to identify the key risks. The targeted respondents of the questionnaire were workers middle management and professionals from the building construction industry in Oman. This Questionnaire consists of six sections: Demographics; Risk Assessment Issues; Risk Assessment Essentials; Attitude and Perception in Risk Assessment; Building Construction Key Risks; Risk
Assessment Process. First, a pilot survey was carried out on 30 respondents to ensure proper perceptions and understanding of the questions. A modified questionnaire forms were then distributed to 540workers, Safety and Health Officers, middle management and professionals. To ensure well distribution, the questionnaire forms were distributed among 75 of excellent and first class building construction companies with no more than 5 forms per company. More than 80 face to face meetings, email communications, and phone discussions were conducted with concerned professionals in different companies to ensure proper understanding of questions and explain the idea of the research. 151 responses were collected as a result of this operation. Some of the companies refused to conduct this survey in their premises after receiving them.

The identified risks in building construction are ideal sample of hazards and can be implemented on other different workplaces.

\section{RESULTS AND DISCUSSION}

The collected data was analysed as follows:

\subsection{Demographics}

All workers who participated in this survey were male gender. Figure 1 shows that about 61 per cent of respondents are young to middle age (below 40 years). This emphasizes the importance of safety procedure due to possible short experience, cost and harm of permanent illness or disability. About 0.7 per cent of respondents were above 60 years old which indicates that the government guide for retirement age of 60 years is not implemented in the construction industry. Figure 2 shows that 59 per cent of respondents were having education equal to or below the national diploma ( $\leq 12$ level). 21.2 per cent were totally illiterate. These figures show how important and expensive to educate these people to elevate their knowledge about safety and health. Figure 3shows that contractors employ 75.5per cent of the workers in the construction industry followed by the consultants (19\%). Since contractors are cost saving oriented, especially, on workers' expenses, it is highly expected to face large number of occupational Safety and health incidents. Figure 4indicates that about 53 per cent of respondents were labourers and technicians and usually these people have least education and age. They are exposed to machines and tools and more vulnerable to incidents. The Health, Safety and Environment HSE officers account for 3.3 per cent among the studied respondents. Several site visits and meetings with projects managers showed that some sites are not attended by HSE officers at all and other sites are only attended during large operations. In addition, this percentage does not ensure well distribution of HSE officers on a basis of number of workers. Some international standards recommend having minimum of one permanent safety personal for each 50 workers(OSH Act [11].Figure 5 shows that 96 per cent of projects are residential, commercial or a combination of residential and commercials. Usually these types of projects are owned by private sectors where least safety and health precautions are 
adopted. Figure 6 shows about 49 per cent of workers were having equal to or less than 5 years of experience and 81.3 per cent less than 10 years of experience in the construction projects. As the construction are the most hazardous working areas, authorities in Oman (such as Ministry of Manpower and Public Authority for Social Insurance) to put minimum work experience in building construction especially for the excellent and first class construction companies. Less experience workers are less familiar with the different types of hazards and this can cause different type of accidents. Figure 7 shows that 53 per cent of respondents never experienced fatality during their work. This number may give wrong expression about safety procedures, but it can be justified when compared with Figure 6 with about 49 per cent of workers have less than 5 years' work period. 9.3per cent of respondents have experienced a fatality in less than a year. This number may increase with the escalation in the number of construction projects. Figure 8 shows that the percentage of participants' experienced major incidents are very high (around 63\%). 8.6per cent of the participants experienced major incidents in less than one year. The percentage of major incidents expected to increase as in between 1 and 5 years the percentage was $19.9 \%$ and with a small difference $(23.8 \%)$ increased between 6 and 10 years.

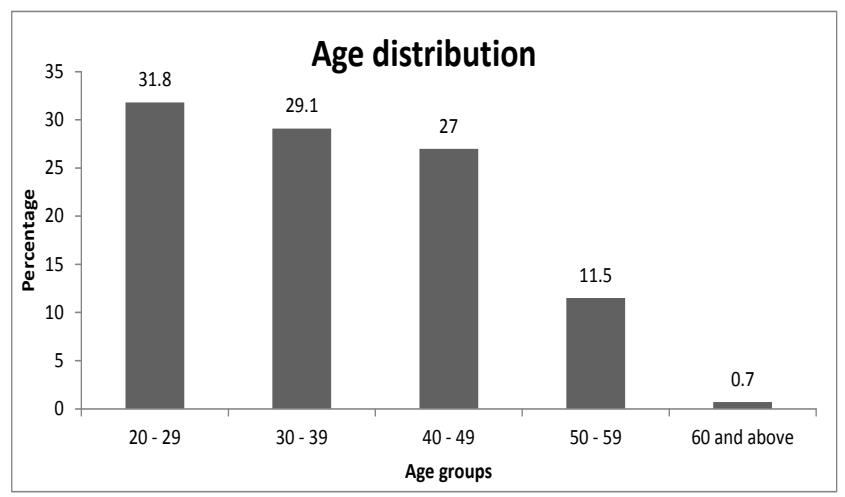

Figure 1: Percentage of age distribution among the questionnaire participants

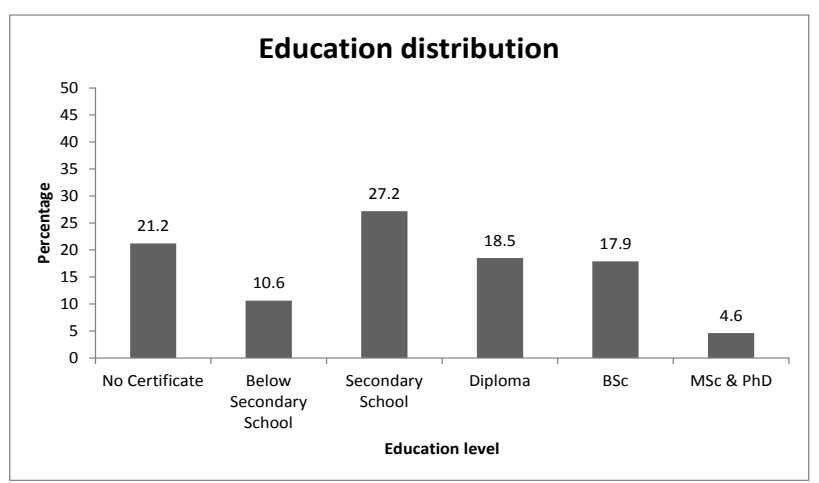

Figure 2: Percentage of education distribution among the questionnaire participants

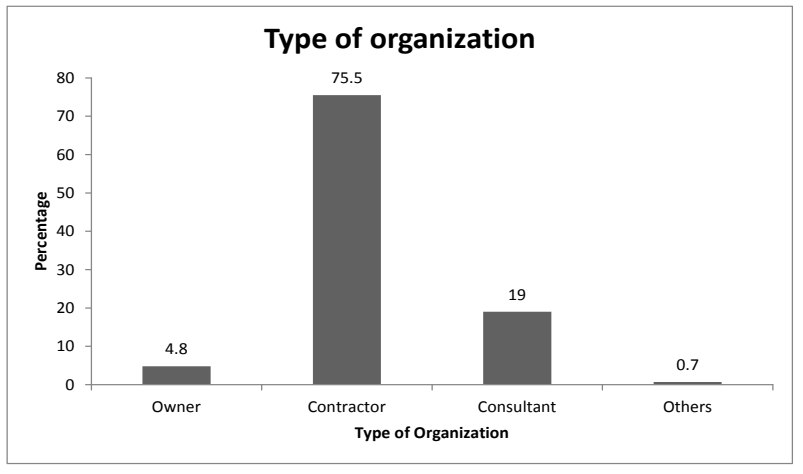

Figure 3: Percentage for the type of organization for the questionnaire participants

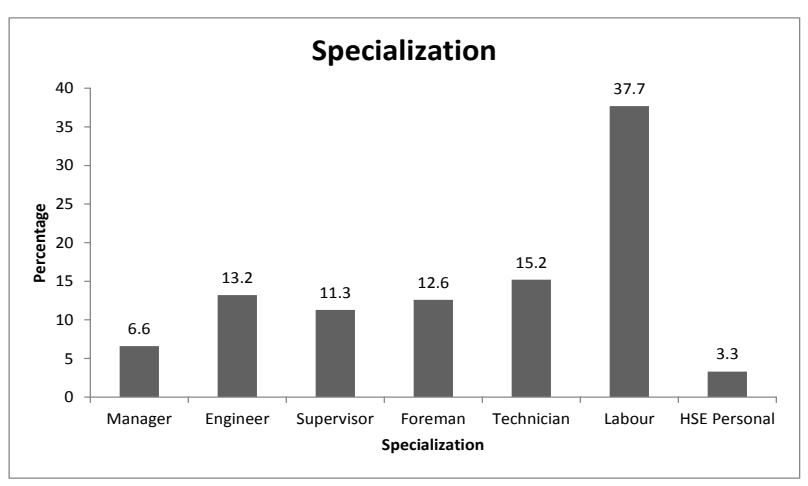

Figure 4: Percentage Specialization for the questionnaire participants

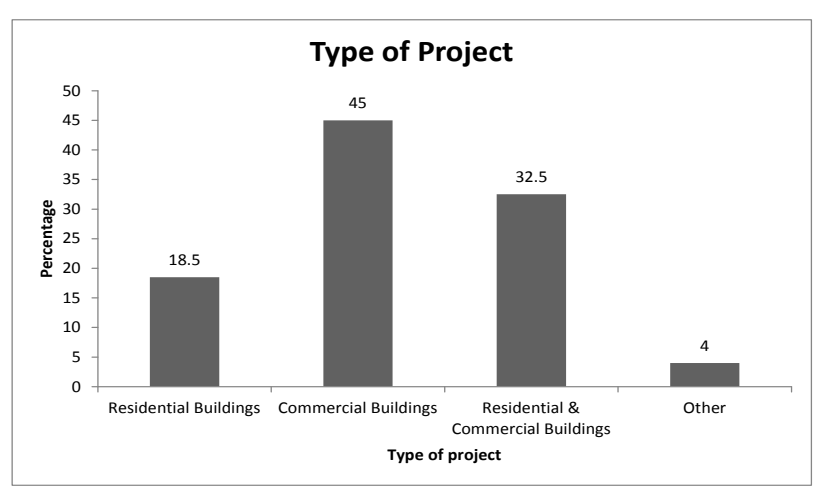

Figure 5:Percentage for the type of projects that participants involved

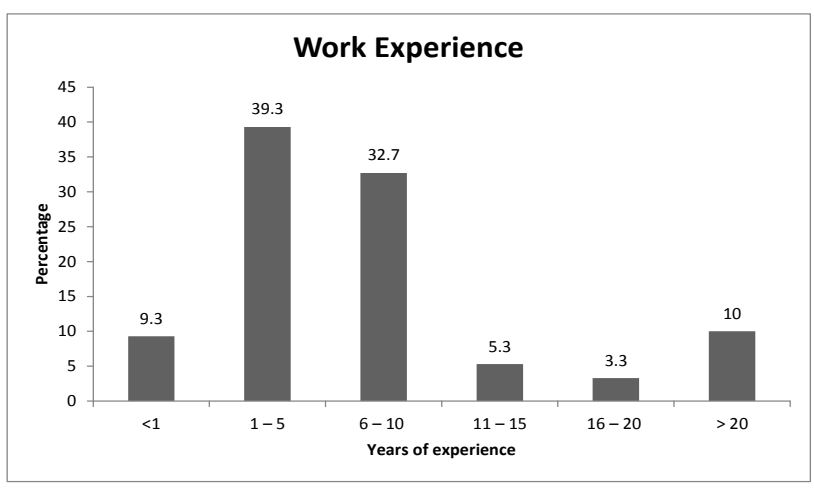

Figure 6: Participants work experience percentage 


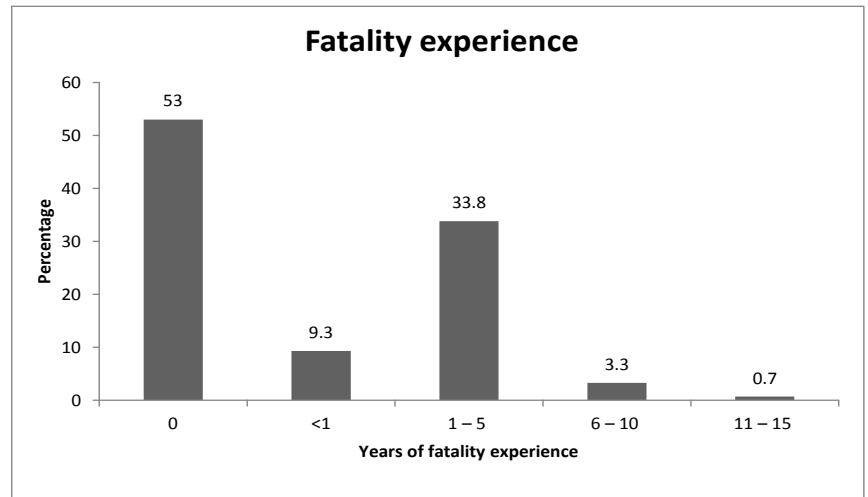

Figure 7: Percentage of participants' fatality during their work experience

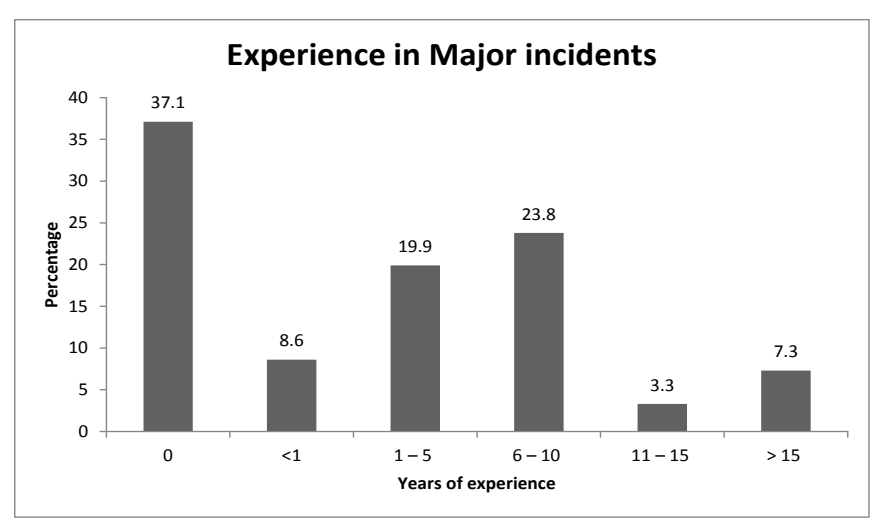

Figure 8: Percentage of participants' major incidents during their work experience

\subsection{Risk Assessment Issues}

Table 1explores the respondents' awareness about risk assessment issues. All participants indicated their knowledge of the term "Risk Assessment". When they were asked whether they know how to carry out risk assessment in professional way, 23.2 per cent could not give a solid answer. Properly they are not sure if they can carry risk assessment in correct way. Other reason to this reluctancy, is lack or insufficient training. 19.9 per cent of the participants clearly admitted that they don't know how to carry out risk assessment in professional way. 57 per cent confirmed knowledge on how to carry out risk assessment in professional way. 66.7per cent of the respondents do not trust that somebody can carry out risk assessment on their behalf. 53.6 per cent of respondents indicated that they do not have Risk Assessment Matrix for Occupational Safety and Health. During site visits it was found that many construction companies do not carry out risk assessment at all. Some companies carryout risk assessment but without clear knowledge of references such as Hazard Identification Studies, HAZID or Hazard and Operability Studies HAZOP. The current matrices evaluate the occupational risks together with other factors such as environmental risks, cost risks and reputation risks. This combination in some cases compromises on workers life and safety. This result supports the idea of having independent Risk Assessment Matrix for Occupational Safety and Health in building construction industry. 54.3 per cent of the respondents said that they had never undergone any certified training in how to carry out risk assessment. Lack of training in how to conduct occupational safety and health risk assessment can lead to fatalities, incidents and near misses. Other workers' concern is carrying out risk assessment on others behalf. Although most employees are not refusing to do the job that they are asked to do, still they are not confidant that they will carryout the work in a safe way because they didn't evaluate the risks themselves. Workers involved in a certain activity should be part of the risk assessment process.

Table 1: Respondents' awareness about risk assessment issues

\begin{tabular}{|l|c|c|c|}
\hline Activity & No\% & $\begin{array}{c}\text { I don't } \\
\text { know \% }\end{array}$ & Yes \\
\hline $\begin{array}{l}\text { Do you know what "Risk } \\
\text { Assessment" is? }\end{array}$ & 0 & 0 & 100 \\
\hline $\begin{array}{l}\text { Do you know how to carry } \\
\text { out risk assessment in } \\
\text { professional way? }\end{array}$ & 19.9 & 23.2 & 57 \\
\hline $\begin{array}{l}\text { Did you get any certified } \\
\text { training in how to carry out } \\
\text { risk assessment? }\end{array}$ & 54.3 & 18.5 & 27.2 \\
\hline $\begin{array}{l}\text { Will you trust somebody } \\
\text { carrying out risk } \\
\text { assessment on your behalf? }\end{array}$ & 66.7 & 12.7 & 20.7 \\
\hline $\begin{array}{l}\text { If "high risk" is reported in } \\
\text { your workplace do you take } \\
\text { an immediate action? }\end{array}$ & 7.3 & 2.6 & 90.1 \\
\hline $\begin{array}{l}\text { If you report a "high risk" } \\
\text { will it be considered by } \\
\text { your supervisor? }\end{array}$ & 31.1 & 2.6 & 66.2 \\
\hline $\begin{array}{l}\text { Are you satisfied with your } \\
\text { Company Risk Assessment } \\
\text { Matrix? } \\
\text { any activity? }\end{array}$ & 12.6 & 0.7 & 45.7 \\
\hline $\begin{array}{l}\text { Do you you have independent } \\
\text { Risk Assessment Matrix for } \\
\text { \&Health? }\end{array}$ & 53.6 & 0.7 & \\
\hline
\end{tabular}




\subsection{Risk Assessment Essentials}

Table 2shows the respondents' replies to "How important is each of the following to you when assessing the occupational Safety and Health in the work place" All respondents agreed that it is important or very important to apply Occupational Risk Assessment Matrix in accordance with the local regulations. Similar results were found for provision and monitoring of risk control measures. All respondents indicated that there it is important or very important to have plan of the premises indicating escape routes, location of fire fighting equipment, alarm system information, emergency lighting, risk storage areas, mains. 100 per cent of respondents answered that it is important or very important to conduct risk assessment before starting any activity. Only 2.6 per cent of respondents indicated that the Occupational Risk Assessment Matrix in Construction is does not need any improvement while 97.4 indicated that it is important or very important to improve the ORA. This part of the study gives alert to local authorities such as Ministry of Manpower and Public Authority for Social Insurance about the need of adopting an ORA procedure. The absence of ORA procedure at the place of work results in increase of fatalities and accidents.

Table 2: Respondents' to "How important is each of the following to you when assessing the occupational Safety and Health in the workplace"

\begin{tabular}{|l|c|c|c|c|}
\hline Activity & $\begin{array}{c}\text { Totally } \\
\text { Unimp } \\
\text { ortant }\end{array}$ & $\begin{array}{c}\text { Unimp } \\
\text { ortant }\end{array}$ & $\begin{array}{c}\text { Import } \\
\text { ant }\end{array}$ & $\begin{array}{c}\text { Very } \\
\text { Impo } \\
\text { rtant }\end{array}$ \\
\hline $\begin{array}{l}\text { Appropriate risk } \\
\text { assessments to be carried } \\
\text { out in accordance with the } \\
\text { requirements of Local } \\
\text { Regulations. }\end{array}$ & 0 & 0 & 25.8 & 74.2 \\
\hline $\begin{array}{l}\text { All necessary risk } \\
\text { reduction/risk control } \\
\text { measures to be } \\
\text { introduced. }\end{array}$ & 0 & 0 & 32.5 & 67.5 \\
\hline $\begin{array}{l}\text { Staff to be trained/ } \\
\text { retrained to provide these } \\
\text { measures. }\end{array}$ & 0 & 2.6 & 68.2 & 29.1 \\
\hline $\begin{array}{l}\text { Risk reduction/risk } \\
\text { control measures to be } \\
\text { monitored to ensure } \\
\text { suitability and } \\
\text { effectiveness. }\end{array}$ & 0 & 0 & 31.1 & 68.9 \\
\hline $\begin{array}{l}\text { There is a procedure in } \\
\text { place to ensure risk } \\
\text { assessment and reviewed } \\
\text { periodically. }\end{array}$ & 0 & 2.6 & 64.9 & 32.5 \\
\hline $\begin{array}{l}\text { There is a plan of the } \\
\text { premises indicating }\end{array}$ & 0 & 0 & 29.1 & 70.9 \\
\hline
\end{tabular}

\begin{tabular}{|l|l|l|l|l|}
\hline $\begin{array}{l}\text { escape routes, location of } \\
\text { firefighting equipment, } \\
\text { alarm system information, } \\
\text { emergency lighting, risk } \\
\text { storage areas, mains } \\
\text { services switch gear etc. }\end{array}$ & 0 & 0 & 9.3 & 90.7 \\
\hline $\begin{array}{l}\text { Conducting risk } \\
\text { assessment before starting } \\
\text { any activity. }\end{array}$ & 0 & 0 & 33.8 & 63.6 \\
\hline $\begin{array}{l}\text { Occupational Risk } \\
\text { Assessment Matrix in } \\
\text { Construction needs to be } \\
\text { improved. }\end{array}$ & 2.6 & & & \\
\hline
\end{tabular}

\subsection{Attitude and Perception in Risk Assessments}

Table 3 shows the respondents' attitude and perceptions regarding occupational risk assessment for safety and health in the work place. Only 42.4 per cent strongly agree to "HSE personal should carry out risk assessment for you before any activity". This means that most of the workers do not see this applied in their workplaces. The opinion of 59.6per cent of the respondents is to stop working in any activity if the workers are unsatisfied with the controlled measures in the workplace. 35 per cent of respondents strongly disagree to have exemptions for risk assessment. 68 per cent of the participants agreed that if main working teams changed, risks need to be reassessed. This finding gives an attention to the local authorities such as Ministry of Manpower and Public Authority for Social Insurance, that a lot of workers and their supervisors are not conducting risk assessment in all activities all times. The assumption of safe work environment is not justified due to hidden fatalities, accidents or near misses.

Table 3: Respondents' attitude and perceptions regarding occupational Risk Assessment for safety and health at workplace

\begin{tabular}{|l|c|c|c|c|c|}
\hline Activity & $\begin{array}{c}\text { Strong } \\
\text { ly } \\
\text { Disagr } \\
\text { ee }\end{array}$ & $\begin{array}{c}\text { Disag } \\
\text { ree }\end{array}$ & $\begin{array}{c}\text { Neu } \\
\text { tral }\end{array}$ & Agree & $\begin{array}{c}\text { Strong } \\
\text { ly } \\
\text { Agree }\end{array}$ \\
\hline $\begin{array}{l}\text { HSE Personal should } \\
\text { carry out risk } \\
\text { assessment for you } \\
\text { before any activity. }\end{array}$ & 9.3 & 3.3 & 6 & 39.1 & 42.4 \\
\hline $\begin{array}{l}\text { Stop working if you } \\
\text { are unsatisfied with the } \\
\text { controlled measures in } \\
\text { your workplace. }\end{array}$ & 0 & 0 & 0 & 40.4 & 59.6 \\
\hline $\begin{array}{l}\text { There are exemptions } \\
\text { for risk assessment? } \\
\text { (When you don't have }\end{array}$ & 35.8 & 39.7 & 4 & 17.2 & 3.3 \\
\hline
\end{tabular}




\begin{tabular}{|l|l|l|l|l|l|}
\hline $\begin{array}{l}\text { to carry out risk } \\
\text { assessment). }\end{array}$ & ( & & & & \\
\hline $\begin{array}{l}\text { If main working teams } \\
\text { changed, risks need to } \\
\text { be reassessed again. }\end{array}$ & 0 & 0 & 4.6 & 68.9 & 26.5 \\
\hline $\begin{array}{l}\text { Risk assessment in } \\
\text { building construction } \\
\text { always needs to be } \\
\text { assesses. }\end{array}$ & 0 & 0 & 0 & 59.6 & 40.4 \\
\hline $\begin{array}{l}\text { Risk assessment in } \\
\text { building construction } \\
\text { to be a mandatory } \\
\text { requirement. }\end{array}$ & 0 & 0 & 6.6 & 43.7 & 49.7 \\
\hline $\begin{array}{l}\text { Employees to be } \\
\text { adequately trained in } \\
\text { all health and safety } \\
\text { aspects of the task. }\end{array}$ & 0 & 0 & 0 & 38.4 & 61.6 \\
\hline $\begin{array}{l}\text { All personnel routinely } \\
\text { carry out risk } \\
\text { assessment not only } \\
\text { carried out by certain } \\
\text { (competent) persons. }\end{array}$ & 3.3 & 0 & 6.6 & 57.6 & 32.5 \\
\hline
\end{tabular}

\subsection{Construction Key Risks}

In Table 4, the sixteen work activities resulted from the interviews with the Safety and Health Experts and risk management staff in the field of construction industry are listed. All activities that received answers of "Always" of score of 70 per cent and above are considered as key risks. It was found that 6 activities are causing key risks; namely: working at heights; working on fragile roofs; using electrical equipment; working under high voltage overhead power lines; working in confined spaces; working without knowing how to use the provided emergency equipment. Low scores were given to "Before demolition and refurbishment", "Before excavations" and "Working using noisy machinery" which indicates that the respondents value these activities with less seriousness based on their experience.

Table 4: Respondents' replies to "How often do you face fatality or accident on the following activities?"

\begin{tabular}{|l|c|c|c|c|c|}
\hline Activity & $\begin{array}{c}\text { Nev } \\
\mathbf{e r}\end{array}$ & $\begin{array}{c}\text { Seldo } \\
\mathbf{m}\end{array}$ & $\begin{array}{c}\text { Some } \\
\text { times }\end{array}$ & $\begin{array}{c}\text { Often } \\
\mathbf{\%}\end{array}$ & $\begin{array}{c}\text { Alwa } \\
\mathbf{y s}\end{array}$ \\
\hline Working at heights & 0 & 0 & 0 & 26.5 & 73.5 \\
\hline Working in fragile roofs & 0 & 0 & 3.3 & 6 & 90.7 \\
\hline $\begin{array}{l}\text { Working in areas where } \\
\text { falling objects are }\end{array}$ & 0 & 2.6 & 0 & 54.3 & 43 \\
\hline
\end{tabular}

\begin{tabular}{|l|c|c|c|c|c|}
\hline without protection & & & & & \\
\hline $\begin{array}{l}\text { Before demolition and } \\
\text { refurbishment }\end{array}$ & 0 & 0 & 19.9 & 36.4 & 43.7 \\
\hline Before excavations & 0 & 2.6 & 0 & 32.5 & 64.9 \\
\hline $\begin{array}{l}\text { Using vehicles on } \\
\text { loading and storage } \\
\text { areas }\end{array}$ & 0 & 0 & 0 & 49 & 51 \\
\hline $\begin{array}{l}\text { Using electrical } \\
\text { equipment }\end{array}$ & 0 & 0 & 2.7 & 17 & 80.3 \\
\hline $\begin{array}{l}\text { Working using noisy } \\
\text { machinery }\end{array}$ & 0 & 0 & 6 & 59.6 & 34.4 \\
\hline $\begin{array}{l}\text { Using flammable } \\
\text { substances }\end{array}$ & 0 & 0 & 2.8 & 36.4 & 60.8 \\
\hline Manual handling & 0 & 0 & 3.5 & 32.9 & 63.6 \\
\hline Lifting operations & 0 & 0 & 0 & 33.1 & 66.9 \\
\hline $\begin{array}{l}\text { Working under high } \\
\text { voltage overhead power } \\
\text { lines }\end{array}$ & 3.3 & 3.3 & 2.6 & 6.6 & 84.1 \\
\hline $\begin{array}{l}\text { Working in confined } \\
\text { spaces }\end{array}$ & 0 & 3.3 & 14.6 & 11.3 & 70.9 \\
\hline $\begin{array}{l}\text { Gas welding } \\
\text { provided emergency } \\
\text { equipments. }\end{array}$ & 0 & 2.6 & 29.8 & 67.5 \\
\hline $\begin{array}{l}\text { Working without } \\
\text { Proaring Personal } \\
\text { (PPE) }\end{array}$ & 0 & 0 & 0 & 45.7 & 54.3 \\
\hline Working without & 0 auipment & 27.2 & 71.5 \\
\hline
\end{tabular}

\subsection{Risk Assessment Process}

Table 5 shows the respondents' replies to "How often do you do the following at construction site?". It is clear that most respondents replied with "always" or "often" which indicates the willingness of applying risk management by workers. The least positive response came for the planning control options which indicates weaknesses in taking adequate control measures for the identified and evaluated risks. This is due to absence of the hierarchy of hazards control or the safety and health of workers are kept as less importance. 
Table 5: Respondents' replies to "How often do you do the following at the construction site"

\begin{tabular}{|c|c|c|c|c|}
\hline Activity & $\begin{array}{c}\text { Never } \\
\%\end{array}$ & $\begin{array}{c}\text { Rarely } \\
\quad \%\end{array}$ & $\begin{array}{c}\text { Often } \\
\quad \%\end{array}$ & $\begin{array}{c}\text { Alway } \\
\text { s } \\
\text { \% }\end{array}$ \\
\hline $\begin{array}{l}\text { Planning } \\
\text { Assessment }\end{array}$ & 0 & 2.6 & 40.4 & 57 \\
\hline $\begin{array}{l}\text { Analyzing Work } \\
\text { Activities }\end{array}$ & 0 & 3.3 & 41.1 & 55.6 \\
\hline $\begin{array}{l}\text { Hazard } \\
\text { Identification }\end{array}$ & 0 & 0 & 25.8 & 74.2 \\
\hline $\begin{array}{l}\text { Estimating } \\
\text { Risks }\end{array}$ & 0 & 3.4 & 12.2 & 84.4 \\
\hline $\begin{array}{l}\text { Evaluating } \\
\text { Risks }\end{array}$ & 0 & 3.3 & 17.9 & 78.8 \\
\hline $\begin{array}{l}\text { Planning } \\
\text { Control } \\
\text { Options }\end{array}$ & 0 & 0 & 52.3 & 47.7 \\
\hline
\end{tabular}

\section{CONCLUSION}

In this research a field survey was conducted via 30 interviews with safety and health experts and risk management staff in the field of construction industry in Oman followed by a questionnaire that was divided into six categories; namely: Demographics, Risk Assessment Issues, Risk Assessment Essentials, Attitude and Perception in Risk Assessments, Construction key Risks and Risk Assessment Process. The aim was to explore the availability, awareness, type and implementation of Occupational Risks Assessment in the construction projects in Oman. Six key risks were identified; namely: working at heights; working on fragile roofs; using electrical equipment; working under high voltage overhead power lines; working in confined spaces; working without knowing how to use the provided emergency equipment. All respondents were male gender and 61 per cent of them were below the age of 40.59 per cent of respondents have education equal to or below the national diploma ( $\leq 12$ level). 75.5 per cent of the respondents work in construction industry followed by the consultants (19\%). 53 per cent of respondents were labourers and technicians. 96 per cent of projects were residential, commercial or a combination of residential and commercials buildings. 49 per cent of workers were having equal to or less than 5 years of experience and 81.3 per cent less than 10 years of experience in the construction projects. 53 per cent of respondents never experienced fatality during their work. 53.6 per cent of respondents indicated that they do not have Risk Assessment Matrix for Occupational Safety and Health. All respondents agreed that it is important or very important to apply Occupational Risk Assessment Matrix in accordance with the local regulations. Only 42.4 per cent strongly agree to "HSE personal should carry out risk assessment for you before any activity". Most respondents showed willingness of applying risk management by workers.

\section{ACKNOWLEDGEMENT}

The authors would like to express their thanksand appreciation to the Ministry of Manpower (Oman), Public Authority for Social Insurance (Oman), and Block 60 HSE Department at Oman Oil Company-Exploration \& Production LLC (OOCEP) for their provision of raw data, continued support, and interaction during the research work. The thanks and appreciation are extended to all those who agreed for interviews and discussions during the preparations of the questionnaire.

\section{COPYRIGHT}

It should be noted that the questionnaire is registered copyright under Universitti Putra Malaysia, Malaysia, and Sultan Qaboos University, Oman.

\section{REFERENCES}

[1] Im H. J., Kwon Y. J., Kim S. G., Kim Y. K., Ju Y. S., and Lee H. P. ( 2009), The characteristics of fatal occupational injuries in Korea's construction industry, 1997-2004. Safety Science, v47, n8, pp1159-1162.

[2] Watfa N., (2009), The National Occupational Safety and Health Profile of The Sultanate Of Oman, Ministry Of Manpower in Collaboration with the International Labor Organization

[3] Hinze J., Jenny N. Devenport J. N. and Giang G. (2006), Analysis of construction worker injuries that do not result in lost time, Journal of Construction Engineering and Management, ASCE, v132, n3,pp321-326.

[4] Baradan S. and Usmen M. A. (2006), Comparative Injury and Fatality Risk Analysis of Building Trades, Journal of Construction Engineering and Management, ASCE, v132, n5, pp533-539.

[5] Cox L. A. Jr. (2008) 'What's wrong with Risk Matrices?', Risk Analysis, v28,n2, (Http://dxdoi.org/10.1111\%2fj.1539-6924.2008.01030.x)

[6] Ho V. (2010) The Risk of Using Risk Matrix in Assessing Safety Risk, IOSH Technical Meeting 6, HKARMS Safety Engineering Lecture Series 2.2.

[7] Pinto A, Nunes I.L, and Ribeiro R.A., (2011), Occupational Risk Assessment in Construction Industry - overview and reflection. Safety Science v49,n5, pp61624.

[8] Nasirzadeh, F., Afshar, A., Khanzadi, M. and Howick, S. (2008), Integrating system dynamics and fuzzy logic 
modelling for construction risk management, Construction Management and Economics, v26, pp11971212

[9] Xiu-e Y. and Zhen Y. Z. (2009), Innovation project investment risk evaluation model, 2009-International Conference on Future Bio Medical Information Engineering, pp409-412.

[10] Imriyas, K. (2009), An expert system for strategic control of accidents and insurers' risks in building construction projects, Expert Systems with Applications, v36,pp4021-4034.

[11] Occupational Health and Safety Act, OHS,(1993), Act No. 85 of 1993, Department of Labour, Republic of South Africa, pp1-27. (www.labour.gov.za). 